\title{
Stereotip Gender dan Wacana Maskulinitas dalam Novel Di Tanah Lada Karya Ziggy Zezsyazeoviennazabrizkie
}

\author{
Tania Intan ${ }^{1}$ \\ ${ }^{1}$ Universitas Padjadjaran, Bandung, Jawa Barat-Indonesia \\ Email: tania.intan@unpad.ac.id
}

\begin{tabular}{llll} 
Submitted & : August $11^{\text {th }}, 2021$ & Revision & :April $26^{\text {th }}, 2021$ \\
Reviewed & $:$ April $13^{\text {th }}, 2021$ & Published & : June 18th, 2021 \\
\hline
\end{tabular}

\begin{abstract}
This study aims to uncover gender stereotypes and discourses of masculinity that are scattered in the novel Di Tanah Lada by Ziggy Zezsyazeoviennazabriskie. The method used is descriptive-qualitative with a gender study approach. Data in the form of words, phrases, and sentences were collected by using literature study techniques and taking notes. The theoretical basis used comes from Connell, Feasey, Kimmel, and Flood. The results show that the novel is narrated from the girl character, Salva, who is innocent and honest. Despite these relative deviations, the novel Di Tanah Lada adopts traditional gender stereotypes. Almost all male characters are depicted as superior, dominant, and become perpetrators of violence, so that they are associated with evil male characters. On the other hand, female characters are shown as inferior, weak, and dependent. The masculinity discourse that is built supports traditional gender stereotypes which are still considered acceptable in the contemporary context.
\end{abstract}

Keywords: gender stereotype; masculinity discourses; Di Tanah Lada; Ziggy Zezsyazeoviennazabriskie

Abstrak: Penelitian ini bertujuan untuk mengungkap stereotip gender dan wacana maskulinitas yang tersebar di dalam novel Di Tanah Lada karya Ziggy Zezsyazeoviennazabriskie. Metode yang digunakan adalah deskriptif-kualitatif dengan pendekatan kajian gender. Data berupa kata, frasa, dan kalimat dikumpulkan dengan teknik studi pustaka dan simak catat. Landasan teoretis yang digunakan berasal dari Connell, Feasey, Kimmel, dan Flood. Hasil penelitian menunjukkan bahwa novel tersebut dinarasikan dari sudut pandang tokoh anak perempuan, Salva, yang bersifat polos dan jujur. Meskipun ada penyimpangan relatif, novel Di Tanah Lada mengadopsi stereotip gender tradisional. Hampir seluruh tokoh laki-laki digambarkan superior, 
dominan, dan menjadi pelaku kekerasan, sehingga dikaitkan dengan karakter laki-laki 'jahat'. Sebaliknya, tokoh perempuan ditampilkan sebagai sosok inferior, lemah, dan dependen. Wacana maskulinitas yang dibangun mendukung pada stereotip gender tradisional yang masih dianggap berterima dalam konteks kekinian.

Kata Kunci: stereotip gender; wacana maskulinitas; Di Tanah Lada; Ziggy Zezsyazeoviennazabriskie

\section{Pendahuluan}

Ziggy Zezsyazeoviennazabriskie adalah penulis perempuan Indonesia yang lahir di Bandar Lampung pada tanggal 10 Oktober 1993. Novel pertamanya terbit pada tahun 2010 dengan judul Indigo Girl. Setelah itu, Ziggy dengan produktif meluncurkan buku-buku baru, dan dalam kurun waktu tujuh tahun, ia telah menerbitkan 27 judul novel (Yuniar, 2017). Ia menulis novel Semua Ikan di Langit yang mendapatkan penghargaan pemenang pertama Sayembara Buku Novel Dewan Kesenian Jakarta pada tahun 2016, dan Jakarta Sebelum Pagi yang terpilih sebagai karya fiksi terbaik Indonesia versi majalah Rolling Stone di tahun yang sama. Ziggy bercita-cita menjadi penulis buku anak, namun karena pasar untuk buku anak tergolong sulit, maka ia pun menjadi penulis novel. Obsesi itulah yang mempengaruhi gaya penulisannya. Zen Hae, seorang sastrawan Indonesia, menilai novel-novel Ziggy kompleks karena menggabungkan cerita anak, fantasi, fiksi ilmiah, dongeng, hingga mitos tentang penciptaan dunia.

Novel Ziggy Zezsyazeoviennazabriskie yang dikaji dalam penelitian ini adalah Di Tanah Lada (2015), yang merupakan pemenang kedua pada Sayembara Buku Novel Dewan Kesenian Jakarta tahun 2014. Novel setebal 250 halaman tersebut dinarasikan melalui sudut pandang dan hasil observasi Salva, tokoh anak perempuan yang mengalami kekerasan dalam keluarganya. Salva (atau Ava) baru berumur 6 tahun namun memiliki pola pikiran yang cukup dewasa dan cerdas untuk anak seusianya. Ia selalu mencari tahu arti dari segala sesuatu yang tidak dipahaminya melalui kamus yang selalu ia bawa, sebuah hadiah dari Kakek Kia. Ketika lahir, Salva sempat diberi nama Saliva (ludah) oleh Papa karena dianggap tidak berguna, namun Mama bersikeras menggantinya. Kedua orang tua Salva itu kerap bertengkar karena Papa sangat kasar pada istri dan anaknya. Setelah kematian Kakek Kia, Salva dan keluarganya pun kemudian pindah ke Rusun Nero. Papa menggunakan uang warisan dari Kakek Kia untuk berjudi di kasino dekat rusun bersama Mama. Di tempat 
yang kumuh itu, Salva bertemu dengan anak laki-laki bernama P yang ditinggalkan ibunya dan hanya tinggal dengan ayahnya yang memperlakukan $\mathrm{P}$ dengan sangat kasar. P baru berumur 10 tahun, tapi ia sangat mandiri dan selalu membawa gitar untuk mengamen. Anak laki-laki itu juga diperlakukan secara tidak layak oleh ayahnya. Pengalaman traumatis Salva dan P ini menanamkan pemahaman pada kedua anak tersebut bahwa semua Papa di dunia ini jahat, sehingga P tidak ingin menjadi Papa dan berharap langsung menjadi Kakek. Salva kemudian memanggil $\mathrm{P}$ dengan nama Pepper. Kedua anak itu pun pergi menuju rumah nenek Isma di Tanah Lada dengan bantuan Mas Arly, dan menjalani petualangan bersama hingga akhir hayat mereka. Novel dengan latar kota Jakarta dan Lampung tahun 2013 ini memotret banyak hal, mulai dari cara berpikir orang dewasa yang rumit, masalah ekonomi, kekerasan dalam rumah tangga, trauma, dan kecenderungan bunuh diri pada anak-anak.

Dari penggambaran situasi yang melibatkan masalah kekuasaan dan kekerasan pada perempuan dan anak dalam novel tersebut, terindikasi adanya permasalahanpermasalahan yang berkaitan dengan dominasi patriarki, yang berkelindan dengan stereotip gender dan wacana maskulinitas. Dominasi tersebut tidak hanya merugikan perempuan, melainkan juga laki-laki sendiri, anak-anak, lansia, dan kelompok marjinal lainnya (Drianus, 2019: 36). Walby (2014) menyatakan bahwa struktur patriarkilah yang menjadi penyebab dominasi. Struktur tersebut memproduksi ketidakadilan gender, yang telah meresap pada berbagai tataran kehidupan, makro dan mikro, sadar dan tidak sadar, privat dan publik. Situasi yang bias gender ini berpotensi melahirkan kekerasan sebagai patologi sosial dalam berbagai level dan bentuk, baik struktural maupun kultural. Kekerasan sendiri sering disebut sebagai salah satu manifestasi dari maskulinitas.

Drianus (2019: 38) mengargumentasikan bahwa maskulinitas merupakan ikon kunci dalam berbagai studi mengenai gender. Dengan demikian, pembahasan maskulinitas tidak dapat dilepaskan dari perspektif gender. Secara umum, maskulinitas dipahami sebagai cara laki-laki menegaskan apa yang diyakini sebagai bentuk kejantanannya (Mosse, 1996: 3). Prinsip tersebut sejalan dengan pandangan Flood (2002), bahwa ada tiga gugus fenomena relevan yang diacu sebagai maskulinitas, yang salah satunya menyebut maskulinitas sebagai strategi laki-laki yang berkuasa atau strategi untuk melanggengkan kekuasaan laki-laki. Stereotip gender ini tidak hanya terjadi dalam konteks dunia nyata, melainkan juga tercipta dalam karya sastra. Fenomena-fenomena tersebut terindikasi terjadi di dalam novel 
Di Tanah Lada, yang menampilkan beberapa tokoh laki-laki yang diposisikan sebagai pihak yang berkuasa atas perempuan dan anak-anak.

Sekilas, alur cerita novel tersebut tampak sederhana karena disampaikan melalui sudut pandang anak-anak dan menggunakan kalimat-kalimat pendek. Namun, Di Tanah Lada memuat konflik yang pelik, yang kerumitannya kemudian menarik perhatian sejumlah peneliti untuk menggunakan novel ini sebagai objek kajian. Beberapa penelitian terdahulu telah ditemukan, di antaranya dilakukan oleh Pamungkas (2016) yang menganalisis aspek stilistika melalui bentuk-bentuk diksi dan retorika dalam novel. Pada penelitian-penelitian lain terhadap novel tersebut, perspektif psikologis digunakan oleh Aeny (2017), Ridwan (2018), dan Angelica (2020). Aeny mengkaji dampak kekerasan dalam rumah tangga terhadap perkembangan jiwa tokoh anak dengan analisis struktural dan teori psikologi perkembangan. Hasil telaahnya menunjukkan bahwa kekerasan diwariskan dan berpengaruh pada perkembangan kejiwaan anak hingga mengubah perilaku. Sedangkan Ridwan membahas dinamika kepribadian tokoh utama, dengan tujuan menemukan berbagai naluri dan kecemasan dalam novel tersebut, melalui pendekatan psikoanalisis Freud. Dari hasil kajiannya yang menggunakan pendekatan objektif dan psikologis, Angelica menemukan bahwa tokoh Salva mengalami masalah kejiwaan karena tidak terpenuhinya kebutuhan dasar yaitu fisiologis, rasa aman, rasa memiliki-dimiliki, kasih sayang, dan penghargaan. Penelitian Dian \& Prastyawanto (2018) mengungkap makna keluarga melalui sudut pandang tokoh anak dengan memanfaatkan teori struktural Todorov yang memuat tiga pokok pemikiran, yaitu aspek verbal, sintaksis, dan semantik. Analisis terfokus pada salah satu aspek verbal yaitu sudut pandang. Hasil penelitian menunjukkan bahwa novel Di Tanah Lada merupakan kritik atas kehidupan orang dewasa dan cara pandang anak tentang keluarga.

Dari paparan tentang kajian terdahulu ini, terungkap bahwa belum ada penelitian yang berfokus pada permasalahan tentang gender dan maskulinitas dalam novel tersebut. Dengan demikian, penelitian ini dapat dilanjutkan dengan mempertimbangkan wilayah kajian yang belum tergarap namun sangat potensial untuk dibincangkan. Penelitian ini secara spesifik bertujuan untuk mengungkap stereotip gender dan wacana maskulinitas di dalam novel Di Tanah Lada karya Ziggy Zezsyazeoviennazabriskie, yang akan dikaji dengan metode deskriptifanalitis. Tahap penelitian dimulai dengan pembacaan tertutup terhadap objek penelitian. Data berupa kata, frasa, dan kalimat yang mengidentifikasi berbagai 
motif cerita yang memungkinkan untuk diabstraksi sebagai stereotip gender dan wacana maskulinitas dikumpulkan dengan teknik studi pustaka dan simak-catat. Membaca bagaimana novel memosisikan para tokoh merupakan salah satu strategi untuk mengenal dan menjaring informasi mengenai isu stereotip gender dan wacana maskulinitas yang hendak dibincangkan. Data yang telah dikumpulkan kemudian diklasifikasi, diinterpretasi, dan dianalisis dengan pendekatan kajian gender sehingga gambaran utuh mengenai hal-hal yang dibahas berhasil didapatkan. Hasil temuan dicatat dan ditarik kesimpulan.

Selanjutnya, untuk melakukan kajian, diperlukan perangkat teoretis yang relevan yang akan dipaparkan pada bagian berikut ini.

\section{Gender, Stereotipe Gender, dan Maskulinitas}

Gender, menurut Oakley yang dikutip Meiliana (2016: 148), bukan merupakan perbedaan yang bersifat biologis, melainkan dikonstruksi oleh masyarakat melalui proses sosial dan kultural yang panjang. Oleh karenanya, gender dapat berubah berdasarkan waktu, tempat, dan kelas. Perbedaan gender (gender differences) ini melahirkan peran gender (gender role) yang bermuara pada terjadinya struktur ketidakadilan seperti marginalisasi, subordinasi, dan kekerasan. Perempuan ditempatkan pada perannya sebagai orang yang merawat anak karena kapasitas hamil dan melahirkan, sehingga terbentuk perbedaan kosntruk sosial yang memunculkan pemilahan peran, perilaku, dan perlakuan (Ariyana, 2017: 283-284).

Dalam kehidupan, setiap individu dituntut untuk menjalani peran gender tertentu. Pada masyarakat yang menganut kultur patriarki, peran gender untuk lakilaki terutama dipengaruhi oleh ideologi maskulin. Ideologi ini, menurut Juliastuti (2000) yang dikutip Poedjianto (2014: 18), melahirkan tuntutan bagi setiap lakilaki untuk tampil maskulin, jantan, dan menempati posisi lebih tinggi daripada perempuan. Sedangkan perempuan, sebagaimana dikutip Primordiyanti (2010: 14) dari Moore (1988), dilekatkan pada gambaran yang dikonstruksi secara sosial sebagai individu dengan sifat feminin, yaitu: emosional, pasif, inferior, dependen, lembut, dan perannya dibatasi pada bidang keluarga. Sebaliknya, laki-laki mewarisi sifat maskulin, yaitu: rasional, aktif, superior, berkuasa, keras, dan berperan di masyarakat. Sementara itu, Connell (2005) menegaskan bahwa maskulinitas bukan oposisi biner dari femininitas. Maskulinitas bukan objek yang terisolasi, melainkan aspek dari struktur yang lebih besar, seperti hierarki sosial. Dengan demikian, usaha 
pendefinisian maskulinitas kontemporer bukan dari ketiadaan femininitas (negasi atas karakter feminin), karena maskulinitas jauh lebih kompleks dari sekedar oposisi biner tersebut.

Stereotip gender, menurut Unger dan Crawford (dalam Mahendra (2017: 107), pada dasarnya adalah keyakinan masyarakat mengenai konsepsi tentang perempuan dan laki-laki. Pemikiran tersebut sejalan dengan Naffziger yang dikutip Hurlock (1978: 215), yang mengungkapkan bahwa stereotip gender memiliki aspek konatif, yaitu berkaitan dengan anggapan tertentu tentang apa yang harus dilakukan oleh suatu kelompok jenis kelamin. Hal ini menunjukkan adanya ketentuan bahwa femininitas merupakan gambaran ideal bagi perempuan dan maskulinitas bagi lakilaki. Perempuan harus merepresi kemarahannya karena telah dikonstruksi sebagai "penyayang dan penyabar", sehingga perempuan yang marah sering dianggap "gila" (Priyatna, 2018: xxv).

Paradigma ini sangat kuat sehingga mempengaruhi kesadaran masyarakat yang menuntut individu untuk berperan sesuai jenis kelaminnya, dan efek yang ditimbulkan, umumnya, perlakuan yang diterima laki-laki lebih menguntungkan daripada perempuan. Patriarki telah menempatkan perempuan dan laki-laki dalam kotak identitas yang tertutup rapat, dan relasi di antara keduanya tidak sejajar, melainkan dalam relasi dominasi. Label superior terutama diberikan kepada kualitas dan perilaku yang melekat pada identitas laki-laki.

Salah satu dampak dari stereotip gender, yang tergambar di dalam novel Di Tanah Lada di antaranya adalah perilaku kasar dan kekerasan yang terutama dilakukan para tokoh laki-laki. Dalam kenyataan, kekerasan merupakan realitas yang telah terjadi sepanjang sejarah dan lebih banyak dialami perempuan. Hal ini terjadi karena adanya ketimpangan dalam relasi gender. Kekerasan merupakan indikasi dari penyalahgunaan kekuasaan, ketidaksetaraan, dan dominasi. Kekerasan pada perempuan, menurut Madsen (2000: 2), merupakan akibat dari anggapan gender bahwa inferioritas perempuan adalah hasil dari keturunan yang ditandai dengan fisik yang lemah, keterbatasan intelektual, dan kecenderungan pada emosi. Stereotip tersebut menempatkan perempuan pada wilayah domestik dan laki-laki yang superior di wilayah publik. Karena perannya sebagai pencari nafkah dan pemimpin, laki-laki merasa berkuasa dan memiliki hak untuk melakukan kekerasan. Stereotip gender ini merugikan perempuan dan sekaligus laki-laki, meskipun tidak semua laki-laki diuntungkan atau dirugikan (Buchbinder, 2013). Ada segelintir laki-laki yang menentukan standar normatif yang menentukan bagaimana seharusnya 
menjadi laki-laki, yang mendominasi laki-laki yang berada pada tepian, pada batas pengecualian (Connell, 2005).

Maskulinitas, menurut Fisērová (2019: 17), ada di semua lini kehidupan, mulai dari bisnis, politik, filsafat, komedi, film fiksi imiah, dan dunia hiburan pada umumnya. Maskulinitas umumnya terlihat, tapi juga dapat tidak terlihat, sebagaimana dinyatakan Kimmel (2012: 5). Feasey (2008: 3) menyatakan bahwa maskulinitas tidak lain merupakan gambaran ideal bagi laki-laki ketika mereka dinilai, diuji, dan dikualifikasi, sehingga maskulinitas dominan menjadi penilaian standar dalam bidang psikologi dan penelitian sosial yang mendidik pemuda untuk menjadi laki-laki yang sesungguhnya. Feasey juga beranggapan bahwa "menjadi seorang laki-laki adalah tidak menjadi perempuan". Sedangkan femininitas menurut Moi, dalam Priyatna (2018: 31), adalah suatu rangkaian karakteristik yang didefinisikan secara kultural, dan bahwa apa yang dianggap 'feminin' bergantung pada siapa yang mendefinisikannya, tempat orang itu berada, dan apa yang telah memengaruhi hidup mereka.

Konsep maskulinitas dan femininitas dibentuk oleh kebudayaan, sehingga sifat-sifat yang dilekatkan dapat berbeda di setiap tempat dan mengikuti perubahan zaman. Dalam kajian Prasetyo (2011: 208), diketahui bahwa pada era sebelum tahun 1980, maskulinitas ditampilkan melalui figur laki-laki kelas pekerja yang mendominasi. Bentuk tubuh sebagai hasil dari pekerjaan kasar dan perilaku lakilaki dewasa matang menunjukkan sisi maskulin. Mulai era tahun 1980, laki-laki ideal digambarkan memiliki sifat alamiah sebagai manusia, yaitu penyayang dan perhatian, dan suka memanjakan diri dengan produk komersial seperti perempuan. Di era tahun 1990, konsep maskulinitas ditandai dengan laki-laki yang cenderung mementingkan waktu senggang dan hobby. Mereka memiliki jiwa tak acuh, bebas, suka bersenang-senang, dan menikmati kegiatan seksual. Pada era tahun 2000, muncul trend laki-laki metroseksual yang ditampilkan media sebagai laki-laki dari kelas menengah (ke atas), memperhatikan fashion, rajin berdandan, rapi, dan tergabung dalam komunitas bergengsi.

\section{Refleksi mengenai Stereotip Gender dalam Novel Di Tanah Lada}

Sebagai narator, Salva melakukan pengamatan yang cukup kritis tentang situasi yang terjadi di sekelilingnya. Ia mencoba memahami ucapan dan tindakan para tokoh yang ada di dekatnya, mulai dari Mama, Papa, Kakek Kia, P, Kak Suri, 
dan Mas Arly. Ia mencerna dan menganalisis sebab dan akibat dari suatu peristiwa, seperti mengapa Papa selalu memukuli dan memarahi Mama, atau mengapa P tidak tinggal dengan Mamanya melainkan dengan Papa P yang jahat dan menempelkan setrika panas pada tangan anaknya. Salva juga mencari tahu arti dari kata-kata yang baru ditemuinya melalui kamus hadiah ulang tahunnya dari Kakek Kia. Bila menemui hambatan dalam menemukan jawaban, ia akan melanjutkan pencarian pada kata-kata lain.

Laki-laki ditampilkan secara dualitas dalam novel Di Tanah Lada, ada lakilaki (dewasa) yang 'baik', yang direpresentasikan oleh Kakek Kia dan Mas Arly, serta laki-laki yang 'jahat' yang diwakili oleh Papa Salva dan Papa P. Sementara tokoh perempuan (dewasa) yang hadir dalam novel tersebut adalah Mama Salva dan Kak Suri. Salva, anak perempuan berumur 6 tahun menjadi narator kisahnya sendiri. Sifat penceritaan dari sudut pandang seorang anak kecil dapat dianggap polos, sesekali tidak fokus, namun sarat dengan kejujuran. Salva sendiri dilengkapi pengarang dengan karakter cerdas dan selalu ingin tahu. Itulah sebabnya, ia selalu membawa kamus yang merupakan hadiah dari Kakek Kia di ulang tahunnya yang kelima. Setiap kali tidak memahami suatu kata yang diucapkan orang dewasa, Salva akan mencarinya di dalam kamus, seperti mengenai arti kata 'berbuat tolol' (hlm. 3), 'judi' (hlm. 8), 'legal' (hlm. 17), dan 'berpasangan' (hlm. 65).

Pembahasan mengenai stereotip gender dan wacana maskulinitas dalam penelitian ini didasari oleh narasi tokoh Salva yang diperoleh dari pengalamannya. Dari awal hingga akhir cerita, secara konsisten ia menggambarkan ayahnya sebagai laki-laki yang sangat menakutkan, sangat kontras dengan ibunya yang disebut sangat lembut dan penyayang.

Seperti ada hantu yang menggentayangi seluruh bagian rumahku. (Kata orang, hantu membuat ruangan jadi dingin). Hanya saja, di dalam sini, hantunya hidup. Hidup, berbadan besar, dan sangat menakutkan.

Nama hantunya Papa. (hlm. 2)

Narator-tokoh anak itu mengasosiasikan ayahnya dengan hantu dan monster, yaitu mahluk gaib yang menyeramkan dan harus dijauhi karena dianggap berbahaya. Konstruksi sosial yang menyatakan bahwa umumnya anak perempuan dekat pada ayah dan anak laki-laki dekat pada ibu tidak berlaku sama sekali dalam novel ini. Laki-laki yang didefinisikan melalui sudut pandang seorang anak ini sangat tidak ideal, karena cenderung menakutkan, tidak ada kesan afeksi sama sekali. Secara 
fisik, Papa pun tidak memiliki penampilan menarik, sebaliknya, dalam pandangan Salva, laki-laki itu sangat menyeramkan.

Tampang Papa memang seram. Dia mirip monster-monster atau raksasa yang ada di buku-buku cerita atau film kartun. Besar, gendut, dan berwajah marah. Seolah-olah, setiap hari ada kecoa yang hinggap di atas makanannya. Itu pernah terjadi sekali, dan Papa marah sekali. Dia membanting meja dan semua makanan di piring kami jadi berantakan. Jadinya tidak ada yang makan pada malam itu. (hlm. 2)

Perilaku seorang anak yang takut pada ayahnya dan dekat dengan ibu ditampilkan dengan sangat jelas. Ia selalu menghindari berada di satu ruangan dengan laki-laki pemarah itu. Bukan hanya Salva dan Mama, hampir seluruh tokoh perempuan dan anak-anak dalam novel Di Tanah Lada menjadi pihak yang tersubordinasi dan selalu disudutkan oleh laki-laki. Situasi ini sesuai dengan dengan gagasan oposisi biner dari Connell bahwa maskulinitas tidak dapat dibentuk tanpa adanya femininitas, namun maskulinitas bukan merupakan lawan dari femininitas. Seseorang dapat saja maskulin sekaligus feminin. Pada laki-laki biasanya disematkan karakter rasional, dan pada perempuan, sifat emosional. Namun, berdasarkan pengamatannya, perilaku Papa diasosiasikan oleh Salva dengan monster, seperti bukan manusia. Papa menyatakan keinginannya tidak dengan cara 'baik-baik' seperti berbicara biasa atau meminta, melainkan menggeram, berteriak, dan membanting barang.

Sikap Papa juga seperti monster. Dia menggeram-geram, berteriak-teriak ke orang-orang hanya karena mereka membawa paha ayam alih-alih dada ayam, menggebrak-gebrak banyak barang, membanting piring favoritku, dan tidur seberesnya dia marah-marah. Dia juga sangat kuat. [...]

Mama tidak bisa jadi monster karena dia tidak kuat. Dia juga tidak suka marah-marah. Mama suka tersenyum, tapi senyumnya selalu tampak sedih. Kecuali kalau dia sedang berkebun. Tapi dia akan tampak sedih lagi karena Papa akan memanggilnya dari dalam dan menyuruhnya berhenti 'berbuat tolol'. (hlm. 2-3)

Demikian pula dengan stereotip perempuan yang hampir selalu dianggap sebagai mahluk inferior. Meskipun dalam konstruksi sosial kerap diposisikan sebagai pihak lemah dan menjadi korban, dalam pandangan tokoh anak-anak, perempuan yang direpresentasikan oleh ibu mereka masing-masing bisa menjadi pihak yang dominan dan menjadi pelaku kekerasan. Meskipun tidak 'sejahat' ayah, ibu pun bisa jadi pihak antagonis karena mereka kerap abai dan tidak peduli pada anaknya. 
Kelemahlembutan perempuan tidak selalu menjadi penanda dari kebajikan, karena bisa jadi mereka 'diam-diam jahat' namun sulit dibuktikan.

“Tapi, aku sayang kamu, kok. Aku bisa jadi Mama kamu."

Pepper menggeleng. "Jangan jadi Mama," katanya. "Mama itu diam-diam jahat. Jahatnya memang nggak seperti Papa. Tapi mereka jahat, meskipun ketahuannya susah." (hlm. 155)

Dalam novel, tokoh Kak Suri ditampilkan sebagai perempuan yang keluar dari normanya. Ia disebutkan bersikap bebas pada laki-laki, tinggal sendiri di rumah susun, dan berganti-ganti pasangan tidur. Ia juga digambarkan bukan merupakan ibu yang baik, karena hamil di luar nikah lalu menyerahkan putranya, P, pada kakaknya. Pemujaan atas kebebasan dan sikap menikmati seks seperti yang dilakukan Kak Suri menunjukkan bahwa perempuan itu mengadopsi sifat maskulin, karena ia memiliki pilihan dan berani menentukan jalan hidupnya sendiri, termasuk dengan menolak mengasuh anaknya. Stereotip perempuan yang pasif, inferior, bergantung, dan lembut, tidak terlihat pada tokoh tersebut.

“Memangnya kamu tahu apa, sih?!" Kak Suri balas membentak. Aku tidak pernah melihat perempuan membentak balik kalau sedang dibentak laki-laki. Mama tidak pernah melakukan itu kepada Papa. (hlm. 138)

Perbedaan peran dan sifat maskulin dan feminin sebagai konstruksi masyarakat, memperkuat anggapan yang menimbulkan ketidakadilan gender, baik bagi perempuan maupun laki-laki. Karena laki-laki digambarkan memiliki fisik besar, agresif, superior, rasional, dan perkasa, maka mereka dianggap pantas ditempatkan di wilayah publik sebagai pencari nafkah dan pembuat keputusan. Pembagian peran ini, selain berlaku pada manusia dewasa, juga terlihat pada kedua anak yang merupakan protagonis novel, yaitu Salva dan P. Dengan penuh rasa tanggung jawab, P memberi perlindungan dan mencari nafkah dengan cara mengamen agar mereka dapat makan dalam perjalanan pelarian mereka menuju Tanah Lada. Salva sebagai pihak yang dilindungi, melakukan apapun yang dapat dilakukannya agar P merasa nyaman dan dekat dengannya.

Dari pembahasan ini, dapat dinyatakan bahwa stereotip gender yang membagi peran di antara perempuan dan laki-laki bersifat tradisional, meskipun ada deviasi yang ditunjukkan oleh tokoh Kak Suri. Selain itu, stereotip feminin yang ditampilkan dalam novel $\mathrm{Di}$ Tanah Lada tidak sebanyak stereotip maskulin karena kecenderungan fokus kisah adalah observasi narator terhadap para tokoh laki-laki. 
Kehadiran para tokoh perempuan cenderung ditujukan untuk memperlihatkan relasi dominasi yang ditampilkan pengarang melalui tokoh-tokohnya. Secara sadar, Ziggy Zezsyazeoviennazabriskie mengindikasikan hadirnya interpolasi superioritas laki-laki pada perempuan.

\section{Konsep Maskulinitas Tradisional dan 'Baru' dalam Novel Di Tanah Lada}

Sebagai manifestasi maskulinitas mereka, laki-laki dikonstruksikan sebagai sosok yang kuat, rasional, serta tidak diizinkan menunjukkan sisi emosional dan sentimentalitas mereka. Laki-laki yang menangis akan dianggap aneh karena menyerupai perempuan yang dianggap lemah dan lembut hatinya. Sejatinya, menjadi laki-laki maskulin berarti mengadopsi nilai-nilai superioritas. Dalam novel Di Tanah Lada, prinsip maskulinitas ditunjukkan terutama melalui narasi tentang sikap dan mental laki-laki para tokoh laki-laki.

Sebagaimana dinyatakan Feasey, seorang laki-laki disebut berkarakter maskulin jika ia tidak menyerupai perempuan. Perempuan dikonstruksi sebagai sosok yang lemah, baik fisik dan mental, termasuk intelektualitasnya. Itulah sebabnya, kelemahan perempuan ditunjukkan dengan perilaku manja dan cengeng/ mudah menangis. Dengan demikian, laki-laki yang menangis dapat dinilai tidak maskulin karena ia berperilaku seperti perempuan.

Aku tidak pernah melihat anak laki-laki menangis. Aku tidak pernah tahu laki-laki menangis sama sekali. Anak perempuan sering menangis. Terutama, kalau rambut mereka ditarik oleh Ade si Gendut Bau Keringat. (hlm. 151-152)

Laki-laki juga tidak akan dianggap maskulin jika takut pada hal-hal yang umumnya ditakuti oleh perempuan, seperti binatang-binatang kecil. Laki-laki juga dinilai tidak pantas mengerjakan pekerjaan rumah tangga yang merupakan aktivitas domestik, yang berarti merupakan wilayah perempuan. Namun, dalam pengamatan narator, ternyata ayahnya yang bertubuh besar, kasar, jahat itu juga takut pada kecoa. Untuk menutupi kelemahan dan mengalihkan perhatian publik (anak kecil) yang mengamatinya, laki-laki itu biasanya menyalahkan Mama yang dianggap lalai membersihkan rumah. Dengan demikian, harga dirinya sebagai lakilaki tetap tinggi dan maskulinitasnya tidak lagi diragukan.

Papa bilang, tolol kalau aku takut kecoa. Tapi dia juga sepertinya takut kecoa. Kalau ada kecoa, dia akan melotot dan mendengus-dengus, lalu menyuruh 
Mama mengusirnya sambil bilang, "KAU INI TIDAK BECUS MEMBERSIHKAN RUMAH! TIDAK BECUS MELAKUKAN APA-APA!”. (hlm. 26)

Bila perempuan ditempatkan di wilayah domestik, laki-laki lebih banyak beraktivitas di luar rumah dengan kegiatan fisik, seperti berolahraga, ke kantor/ pabrik, ke tempat perjudian. Sedangkan Mama digambarkan hanya pergi keluar rumah untuk berbelanja di pasar atau menemani Papa ke kasino, yang berarti masih berkaitan dengan fungsinya sebagai ibu/ istri. Sebaliknya, para tokoh Papa dalam novel Di Tanah Lada digambarkan secara konsisten sebagai sosok yang bebas bepergian selain sering menindas perempuan. Papa Salva, misalnya, berkarakter sangat dominan dalam keluarga itu, selain karena berwatak kasar dan memiliki peran sebagai kepala keluarga, ia juga menyimpan kekayaan cukup banyak berkat warisan dari Kakek Kia. Sebaliknya, Mama digambarkan sangat lemah dan bergantung pada suaminya itu. Meskipun mengalami kekerasan secara verbal dan nonverbal, perempuan itu tidak berubah menjadi pribadi yang tangguh. Ia seperti telah terbiasa dan kebal dengan segala perlakuan buruk yang diterimanya. Ia tidak akan makan jika laki-laki itu belum pulang, dan membiarkan laki-laki itu memarahi dan memakinya. Namun, bila keselamatan anaknya terancam, perempuan itu pun tidak segan melawan dengan sekuat tenaga.

Tapi Papa menjerit memarahiku tentang tidur di atas pakaian dengan 'badan kotor anak harammu'. Papa berusaha menutup koper sementara aku masih berbaring di dalamnya, tapi Mama terus-terusan berusaha mendorongnya. Papa mendorong Mama sebagai balasan. Mama terjatuh di lantai. Papa menamparnya, lalu berusaha menutup koperku lagi. (hlm. 74-75)

Meskipun sangat melindungi Salva dan selalu merawatnya dengan baik, Mama tidak berani meninggalkan Papa karena ia rentan secara finansial dan bergantung pada laki-laki itu. Mama juga menggunakan alasan menjaga keutuhan keluarga demi anak dan demi nama baik keluarga. Wacana maskulinitas yang dibentuk melalui fenomena tersebut adalah bahwa perempuan selalu dianggap lemah posisinya dan membutuhkan perlindungan. Dependensi ini berdampak pada penguatan citra laki-laki sebagai pihak yang berkuasa dan superior. Berbeda dengan laki-laki yang tidak memiliki batas dalam melangkah dan dapat bertindak semaunya, perempuan kerap dibatasi oleh wilayah domestik, dengan kepentingan anak termasuk di dalamnya. Sifat keibuan sebagai bentuk femininitas yang melekat pada perempuan membuatnya kuatir pada nasib diri dan anaknya, jika ia meninggalkan laki-laki yang telah menempatkannya dalam kondisi terepresi. 
Maskulinitas kerap dikaitkan dengan kekerasan yang dilakukan laki-laki pada perempuan. Menurut Guamarawati (2009: 45), ada kesamaan pada kasus kekerasan yaitu pelaku merasa dirinya lebih kuat dibandingkan dengan korbannya yang lebih lemah. Pelaku kekerasan akan memilih korban yang tidak lebih kuat darinya, yang dalam konteks novel Di Tanah Lada, pelaku adalah Papa dengan korban adalah Mama dan Salva, putri mereka. Selain menakuti anak-anak secara psikologis, para tokoh laki-laki juga tega melakukan kekerasan fisik yang meninggalkan trauma.

"Aku tidak suka tikus. Aku juga tidak suka hantu. Aku mau menangis, tapi aku ingat kalau Papa benci sekali kalau aku menangis. Mungkin, bukan cuma sisir, aku juga akan dipukul pakai sapu kalau ketahuan menangis. (hlm. 24)

"Dengar, Sayang. Kamu bisa pulang sekarang? Kamu tahu jalan pulang? Mama tidak bisa meninggalkan Papa. Kalau Papa tahu Mama pergi, dia akan mengamuk. Kita berdua bisa dipukulinya. Nah, kamu pulang saja. Kunci pintunya ... kuncinya di ..." (hlm. 36).

Perilaku kasar dan agresif laki-laki yang dilakukan pada perempuan seperti dianggap berterima, dibiarkan, atau dimaklumi, baik oleh korban maupun lingkungannya karena merupakan bukti atas maskulinitasnya. Kecenderungan perempuan dan anak untuk mengalah bahkan menyembunyikan kekerasan yang dilakukan oleh laki-laki (suami/ ayahnya) tersebut menunjukkan penerimaan atas takdirnya sebagai perempuan/ pihak yang posisinya inferior. Dengan menampilkan bagaimana cara perempuan dan laki-laki direpresentasikan dan diatur seperti ini, secara tidak sadar, kedua tokoh anak mempelajari hal-hal tersebut dan menerimanya sebagai sesuatu yang normal, yang membentuk pandangannya tentang dunia. Pada titik jenuh mereka, Salva dan P tidak dapat menerima perlakuan seperti itu lagi hingga dengan sadar dan berani, mereka melakukan perlawanan dengan cara pergi meninggalkan rumah dan menolak menyerupai orang tua masing-masing.

Tokoh Papa juga memenuhi ciri maskulin lain, yaitu memiliki keberanian untuk mengambil resiko. Kesukaannya bermain judi dan kesembronoan memindahkan keluarganya ke Rusun Nero yang kumuh dari rumah yang lebih nyaman merupakan bukti dari sifat bebas dan sewenang-wenangnya. Maskulinitas memberi keleluasaan pada laki-laki itu untuk berkompetisi dan bertaruh, karena tidak ada seorang pun yang menghalanginya.

Kata Mama, kalau melakukan perbuatan tidak baik, itu berarti kita dibujuk setan. Judi adalah perbuatan tidak baik, menurut Mama. Jadi, Papa diajak setan untuk berjudi. Orang-orang yang berjudi semuanya diajak setan. Papa bilang. 
Teman-temannya yang mengajak dia judi. Jadi, teman-temannya itu setan. Dan, kalau Papa mengajak orang lain untuk berjudi, Papa juga setan. Jadi benar kalau aku bilang Papa adalah setan. (hlm. 323)

Dalam konteks keluarga P, Papa P tidak memberi nama pada putranya karena menyangkalnya sebagai keturunan. Pada bagian menjelang akhir novel, ada penjelasan bahwa P sebenarnya adalah anak dari Mas Arly dan Kak Suri yang dititipkan pada kakak Kak Suri sejak bayi (hlm. 223).

"Memangnya, kenapa sih, Papa kamu kasih kamu nama 'P'?" tanyaku, sambil mengutak-atik barang-barang di atas meja. "Papa juga benci aku. Tapi, dia kasih nama betulan. Bukan cuma satu huruf.' [...]

"Kata dia, orang punya nama. Dia nggak menganggap aku orang, jadi aku nggak dikasih nama." (hlm. 88)

"Aku benci Papa. Aku nggak mau tidur di dalam kardus di bawah meja makan. Aku nggak mau dibakar setrika." [...]

"Mas Alri sama aja kayak Papa," bantah P. "Soalnya, dia nggak peduli sama aku. Dia nggak peduli aku dijahatin Papa sementara dia nggak tahu ada di mana." (hlm. 222)

Pengecualian relatif ditunjukkan oleh Mas Alri, ayah P yang sebenarnya. Meskipun pernah mengabaikan anaknya itu, pada saat mapan, laki-laki itu berusaha mendekati P kembali dan menghidupinya dengan layak. Tokoh tersebut dinilai oleh narator sebagai laki-laki yang tidak menyerupai para Papa lainnya, karena memiliki sifat nurturing 'merawat', seperti stereotip yang selalu dilekatkan pada perempuan. Ia membeli makanan, menyuapi, mau mendengarkan anak-anak itu bercerita padanya, meskipun pada akhirnya diketahui Mas Arli pun hampir sama buruknya dengan tokoh laki-laki lainnya.

"Jadi mama dan papa yang baik itu gimana caranya?" tanyaku.

Mas Alri menggeleng. "Mas nggak bisa ngasih tahu kamu. Mas Alri juga bukan papa yang baik."

"Kenapa, Mas?"

Aku memandangi Mas Alri. Dia tampaknya sedih. (hlm. 200)

Simpulan narator bahwa semua Papa jahat merupakan hasil dari nalar induktifnya terhadap setiap kejadian yang ia alami maupun cerita yang ia dengar dari tokoh lain. Dalam perspektifnya, para tokoh laki-laki digambarkan mendapatkan 
keuntungan dari dominasinya atas perempuan, yang ditampilkan secara inferior, kerdil, dan lemah. Selain pada pasangannya, dominasi juga dilakukan kepada anakanak sebagai pihak yang tersubordinasi, melalui tindakan otoriter para orang tua dengan alibi 'mendidik'.

\section{Simpulan}

Dari hasil analisis terhadap novel Di Tanah Lada, diketahui bahwa sebagai pengarang, Ziggy Zezsyazeoviennazabriskie masih mengadopsi stereotiop gender dan wacana maskulinitas tradisional dalam karyanya. Hampir seluruh tokoh laki-laki digambarkan sesuai dengan konsep maskulinitas sebagaimana yang masih berlaku di masyarakat hingga saat ini, yaitu kuat, dominan, dan dekat dengan kekerasan. Laki-laki juga ditampilkan berjiwa bebas dan suka bersenang-senang. Namun, ada konsep maskulinitas baru yang ditawarkan novel ini melalui representasi tokoh Mas Arly. Berbeda dengan para Papa yang lain, ia memiliki karakter baik hati, humoris, dekat dengan anak-anak, dan mau mendengarkan. 'Pelanggaran' atas stereotip gender juga dilakukan oleh Kak Sury, perempuan yang cenderung menunjukkan dominasi atas laki-laki dengan mengutamakan prinsip kebebasan dalam hidupnya.

Wacana maskulinitas yang tersebar dalam novel tersebut juga mendukung pada stereotip gender tradisional. Laki-laki digambarkan sebagai sosok yang berani, kasar, pengambil keputusan, senang berkompetisi dan bertaruh. Sebaliknya perempuan digambarkan sebagai pelengkap atau korban dari maskulinitas.

\section{Daftar pustaka}

Aeny, I. L. (2017). Dampak Kekerasan dalam Rumah Tangga (KDRT) terhadap Perkembangan Kejiwaan Anak pada Novel Di tanah Lada Karya Ziggy Zezyazeoviennazabriskie Tinjauan Psikologi Perkembangan (Skripsi), Universitas Diponegoro, Semarang.

Angelica, L. F. (2020). Konflik Batin Tokoh Utama dalam Novel Di Tanah Lada Karya Ziggy Zezsyazeoviennabrizkie: Kajian Psikologi Sastra. (Skripsi), Universitas Sanata Dharma, Yogyakarta.

Ariyana. (2017). Kajian Perspektif Feminis dalam Novel Padang Bulan dan Cinta di dalam Gelas dalam Analisis Gender. Yin Yang Jurnal Studi Gender dan Anak, 12(2), 279-298. 
Buchbinder, D. (2013). Studying Men and Masculinities. London: Routledge.

Connell, R. W., \& Messerschmidt, J. W. (2005). Hegemonic Masculinity: Rethinking the Concept. Gender \& Society, 19(6), 829-859.

Dian, U. N., \& Prastyawanto, B.D. (2018). Konstruksi Keluarga oleh Tokoh Anak dalam Novel Di Tanah Lada Karya Ziggy Zezsyazeoviennazabriskie. Mozaik Humaniora, 18(2), 235-243.

Drianus, O. (2019). Hegemonic Masculinity Wacana Relasi Gender dalam Tinjauan Psikologi Sosial. Psychosophia Journal of Psychology, Religion, and Humanity, 1(1), 36-50.

Feasey, R. (2008). Masculinity and Popular Television. Edinburgh: Edinburgh University Press.

Fišerová, P. (2019). Monster to Monster: Masculinity as an Invisible Major Theme in Hunter's Run. Journal of International Women's Studies, 20(3 Selected papers from the Fourth, World Conference on Women's Studies, Colombo Sri Lanka), 17-27.

Flood, M. (2002). Between Men and Masculinities: An Assesment of the Term "Masculinity" in Recent Scholarship on Men. In S. M. Pearce, V. (Ed.), Manning the Next Millennium: Studies in Masculinities. Bentley: Black Swan Press.

Guamarawati, N. A. (2009). Suatu Kajian Kriminologis Mengenai Kekerasan terhadap Perempuan dalam Relasi Pacaran Heteroseksual. Jurnal Kriminologi Indonesia, 5(1).

Hurlock, E. B. (1978). Perkembangan Anak Jilid 2 (M. Tjandrasa, Trans.). Jakarta: Erlangga.

Aeny, I. L. (2017). Dampak Kekerasan dalam Rumah Tangga (KDRT) terhadap Perkembangan Kejiwaan Anak pada Novel Di tanah Lada Karya Ziggy Zezyazeoviennazabriskie Tinjauan Psikologi Perkembangan (Skripsi), Universitas Diponegoro, Semarang.

Angelica, L. F. (2020). Konflik Batin Tokoh Utama dalam Novel Di Tanah Lada Karya Ziggy Zezsyazeoviennabrizkie: Kajian Psikologi Sastra. (Skripsi), Universitas Sanata Dharma, Yogyakarta.

Ariyana. (2017). Kajian Perspektif Feminis dalam Novel Padang Bulan dan Cinta di dalam Gelas dalam Analisis Gender. Yin Yang Jurnal Studi Gender dan Anak, 12(2), 279-298. 
Buchbinder, D. (2013). Studying Men and Masculinities. London: Routledge.

Connell, R. W., \& Messerschmidt, J. W. (2005). Hegemonic Masculinity: Rethinking the Concept. Gender \& Society, 19(6), 829-859.

Dian, U. N., \& Prastyawanto, B.D. (2018). Konstruksi Keluarga oleh Tokoh Anak dalam Novel Di Tanah Lada Karya Ziggy Zezsyazeoviennazabriskie. Mozaik Humaniora, 18(2), 235-243.

Drianus, O. (2019). Hegemonic Masculinity Wacana Relasi Gender dalam Tinjauan Psikologi Sosial. Psychosophia Journal of Psychology, Religion, and Humanity, 1(1), 36-50.

Feasey, R. (2008). Masculinity and Popular Television. Edinburgh: Edinburgh University Press.

Fišerová, P. (2019). Monster to Monster: Masculinity as an Invisible Major Theme in Hunter's Run. Journal of International Women's Studies, 20(3 Selected papers from the Fourth, World Conference on Women's Studies, Colombo Sri Lanka), 17-27.

Flood, M. (2002). Between Men and Masculinities: An Assesment of the Term "Masculinity" in Recent Scholarship on Men. In S. M. Pearce, V. (Ed.), Manning the Next Millennium: Studies in Masculinities. Bentley: Black Swan Press.

Guamarawati, N. A. (2009). Suatu Kajian Kriminologis Mengenai Kekerasan terhadap Perempuan dalam Relasi Pacaran Heteroseksual. Jurnal Kriminologi Indonesia, 5(1).

Hurlock, E. B. (1978). Perkembangan Anak Jilid 2 (M. Tjandrasa, Trans.). Jakarta: Erlangga.

Kimmel, M. S. (2012). The History of Men: Essays in the History of American and British Masculinities: SUNY Press.

Madsen, D. L. (2000). Feminist Theory and Literary Practice. London: Pluto Press.

Mahendra, I. (2017). Stereotip Gender dan Penyebaran Wacana Maskulinitas dalam Novel Balada Si Roy: Joe Karya Gola Gong. Alayasastra, 13(2), 105-118.

Meiliana, S. (2016). Fenomena Kekerasan Gender dalam Novel-novel Karya Danielle Steel. Litera, 15(1), 147-159.

Mosse, G. L. (1996). The Image of Man: The Creation of Modern Masculinity. New York: Oxford University Press. 
Pamungkas, S. A. (2016). Analisis Stilistika Novel Di Tanah Lada Karya Ziggy Zezyazeoviennazabrizkie dan Relevansi Sebagai Materi Ajar Bahasa Indonesia di Sekolah Menengah Atas. (Skripsi), Universitas Sebelas Maret, Surakarta.

Poedjianto, S. A. (2014). Representasi Maskulinitas Laki-laki Infertil dalam Film Test Pack karya Ninit Yunita. (Tesis), Universitas Airlangga, Surabaya.

Prasetyo, A. B. (2011). Maskulinitas dalam L-MEN Jurnal Komunikator, 3(2).

Primordiyanti, F. (2010). Maskulinitas dalam Novel Revolutionary Road karya Richard Yates. (Tesis), Universitas Indonesia, Depok.

Priyatna, A. (2018). Kajian Budaya Feminis Tubuh, Sastra, dan Budaya Pop. Yogyakarta: Arti Bumi Intaran.

Ridwan, H. (2018). Dinamika Kepribadian Tokoh dalam Novel Di Tanah Lada Karya Ziggy Zezsyazeoviennazabrizkie Sebuah Kajian Psikoanalisis Sigmund Freud. Jurnal Artikulasi, 2(1), 1-23.

Walby, S. (2014). Teorisasi Patriarki (M. K. Prasela, Trans.). Yogyakarta: Jalasutra.

Yuniar, N. (2017). Bincang-bincang bersama Ziggy Zezsyazeoviennazabriskie. AntaraNews.com. https://www.antaranews.com/berita/619352/bincangbincang-bersama-ziggy-zezsyazeoviennazabrizkie-1 diakses tanggal 19 Juli 2020

Zezsyazeoviennazabrizkie, Z. (2015). Di Tanah Lada (M. Yulistianti Ed. 1 ed.). Jakarta: PT Gramedia Pustaka Utama. 